\title{
Review \\ The Role of Histone Deacetylase 3 Complex in Nuclear Hormone Receptor Action
}

\author{
Sumiyasu Ishii
}

check for

updates

Citation: Ishii, S. The Role of Histone Deacetylase 3 Complex in Nuclear Hormone Receptor Action. Int. J. Mol. Sci. 2021, 22, 9138. https://doi.org/ 10.3390/ijms22179138

Academic Editor: Noriyuki Koibuchi

Received: 15 July 2021

Accepted: 19 August 2021

Published: 24 August 2021

Publisher's Note: MDPI stays neutral with regard to jurisdictional claims in published maps and institutional affiliations.

Copyright: (C) 2021 by the author. Licensee MDPI, Basel, Switzerland. This article is an open access article distributed under the terms and conditions of the Creative Commons Attribution (CC BY) license (https:// creativecommons.org/licenses/by/ $4.0 /)$.
Department of Integrative Physiology, Gunma University Graduate School of Medicine, Maebashi 371-8501, Japan; sishii@gunma-u.ac.jp

\begin{abstract}
Nuclear hormone receptors (NRs) regulate transcription of the target genes in a liganddependent manner in either a positive or negative direction, depending on the case. Deacetylation of histone tails is associated with transcriptional repression. A nuclear receptor corepressor (N-CoR) and a silencing mediator for retinoid and thyroid hormone receptors (SMRT) are the main corepressors responsible for gene suppression mediated by NRs. Among numerous histone deacetylases (HDACs), HDAC3 is the core component of the N-CoR/SMRT complex, and plays a central role in NR-dependent repression. Here, the roles of HDAC3 in ligand-independent repression, gene repression by orphan NRs, NRs antagonist action, ligand-induced repression, and the activation of a transcriptional coactivator are reviewed. In addition, some perspectives regarding the non-canonical mechanisms of HDAC3 action are discussed.
\end{abstract}

Keywords: histone deacetylase 3; nuclear hormone receptor; nuclear receptor corepressor; silencing mediator for retinoid and thyroid hormone receptors

\section{Introduction}

The endocrine system is one of the major mechanisms that contributes to cell-specific functions and homeostasis. Hormones are produced in the endocrine glands and delivered to the whole body by the bloodstream. Although numerous cells are exposed to these hormones, only target cells that express hormone-specific receptors are able to transduce the signal. Hormones are mainly derived from three origins: peptides, cholesterol, and amino acids. Genes for peptide hormones are encoded in the genome, and the hormones are produced through transcription, translation, and posttranslational modification. These hormones are hydrophilic. Hormones synthesized from cholesterol are lipophilic, and include estrogen, progesterone, testosterone, glucocorticoid, and mineralocorticoid. Hormones derived from amino acids are either hydrophilic or lipophilic. One lipophilic example is thyroid hormone. Despite its lipophilic nature, thyroid hormone is transferred into the cells largely by membrane transporters, such as the monocarboxylate transporter 8 (MCT8) [1], rather than by diffusion. Whereas many peptide hormones bind to membrane-associated receptors, the receptors for a group of small lipophilic hormones mainly regulate the transcription of target genes in the nuclei [2]. These receptors are termed nuclear hormone receptors (NRs). NRs bind to the regulatory region of the target genes, typically as dimers, and regulate transcription in a ligand-dependent manner [2].

NRs constitute a large superfamily with at least 65 members [3,4]. These receptors share a common molecular structure [5,6]. The most highly conserved region is the DNAbinding domain, which contains two zinc finger motifs [7,8]. This region is responsible for the binding of the receptor to the specific DNA sequences, called hormone response elements (HREs), on the target genes. Two zinc finger motifs in NRs typically recognize the hexameric DNA motif PuGGTCA (Pu means A or G), although many exceptions exist. When NRs work as dimers, two hexameric core motifs are located as palindromes, direct repeats, or everted repeats, with or without some spacer nucleotides. The $N$-terminal 
region is highly variable and harbors an autonomous transcriptional activation function, which is independent of the ligands [9]. The ligand binding domain (LBD) at the Cterminus is responsible not only for ligand binding, but also for receptor dimerization and transcriptional activation or repression of the target genes $[10,11]$. The transcriptional regulation by NRs is mediated mainly by the interaction with coregulators, including coactivators and corepressors [12]. Basically, NRs suppress transcription in coordination with corepressors, and coactivator interaction is responsible for transcriptional activation by NRs.

Epigenetic histone modifications are highly correlated with transcriptional regulation $[13,14]$. Among numerous modifications, acetylation of lysine residues in $N$-terminal histone tails is one of the most established marks of an open chromatin structure and transcriptional activation [15-17]. Whereas many coactivators exhibit histone acetyltransferase (HAT) activity [18,19], corepressor complexes tend to possess histone deacetylase (HDAC) activity $[20,21]$. Although there are several HDACs, HDAC3 plays pivotal roles in NRdependent signal transduction. In addition to tail parts, core histones are also the targets of acetylation [22]. Several types of histone modifications are also involved in transcriptional regulation, such as methylation, phosphorylation, ubiquitylation, glycosylation, and so on $[23,24]$. These modifications sometimes cooperate with each other and additively or synergistically regulate transcription.

In this review, the basics of the molecular action of NRs will be explained first. The topic will be mainly focused on coregulators and histone acetylation status. Then, the history of HDAC3 as the regulator of NR action will be overviewed. Finally, the molecular mechanisms of NR-HDAC3 functions will be reviewed on each case.

The repressive mechanism of NRs has been mainly explained by corepressor proteins. Although it is established that HDAC3 is the specific core component of the corepressor complex in NR action, the direct involvement of HDAC3 in the NR-dependent repression has not been extensively studied as compared to the roles of corepressors. Given the importance of histone deacetylation by HDAC3, this review will focus on what has been proven about the role of HDAC3 in the NR-dependent repression, rather than the roles of corepressors.

\section{Basics of Molecular Action of Nuclear Hormone Receptors}

\subsection{Heterodimeric Nuclear Hormone Receptors}

NRs bind HREs as heterodimers with a retinoid $X$ receptor (RXR), homodimers, or monomers, and regulate transcription of the target genes [25]. A group of NRs, including a thyroid hormone receptor (TR), a retinoic acid receptor (RAR), and a vitamin D receptor (VDR) form heterodimers with RXR on their target genes. The $N$-terminal regions of these NRs are relatively small. This group of NRs were classically called "type 2 NRs" [26], but this term is no longer commonly used.

In the absence of ligands, these NRs are associated with corepressor complexes that possess HDAC activity and suppress the transcription of the target genes, which is called ligand-independent repression [27-29]. Two major corepressor molecules for NRs are a nuclear receptor corepressor ( $\mathrm{N}-\mathrm{CoR})[30]$ and a silencing mediator for retinoid and thyroid hormone receptors (SMRT, also known as N-CoR2) [31]. These two corepressors are approximately $270 \mathrm{kDa}$ molecules, and share sequence similarities with each other. They also exhibit several common functions, but are not completely redundant, because conventional knockout mice are lethal for both molecules [32,33]. However, these two molecules do not harbor deacetylase activity by themselves. N-CoR and SMRT exhibit HDAC activity as protein complexes that contain HDAC3 (described later). When the ligands are present, corepressors dissociate from NRs, and coactivators are recruited instead (Figure 1a) [34,35]. These coactivators with HAT activity include the p160 family [36-39], which further recruit other HATs, such as the CREB binding protein and p300 [40,41]. This exchange is mainly due to the conformational change of NRs induced by ligands. The unliganded NRs favor binding to corepressors. Upon ligand binding, the LBD undergoes a structural transition called the "mousetrap" mechanism, which allows the interaction 
with coactivators [42]. The LBDs of NRs consist of 12 helices. Helix H12 is the extreme C-terminal part of NRs, and extends toward the outside without a ligand. Upon the binding of ligands, helix $\mathrm{H} 12$ changes its position and covers the core LBD region like a "mousetrap". The cofactor exchange does not actually follow such an "all-or-none" switch model. It was revealed in vivo that the expression of TR-target genes is regulated by a shift in the relative binding of corepressors and coactivators [43]. It should be noted that these NRs similarly work as homodimers, depending on the target genes.
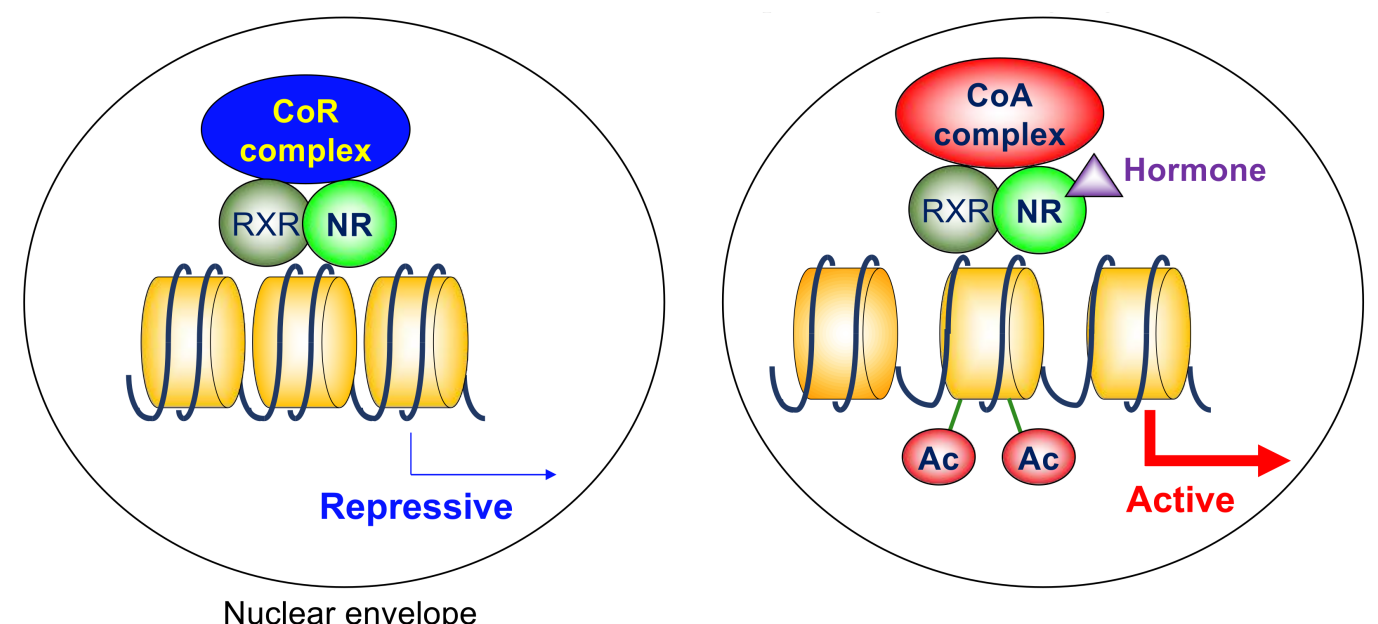

(a)
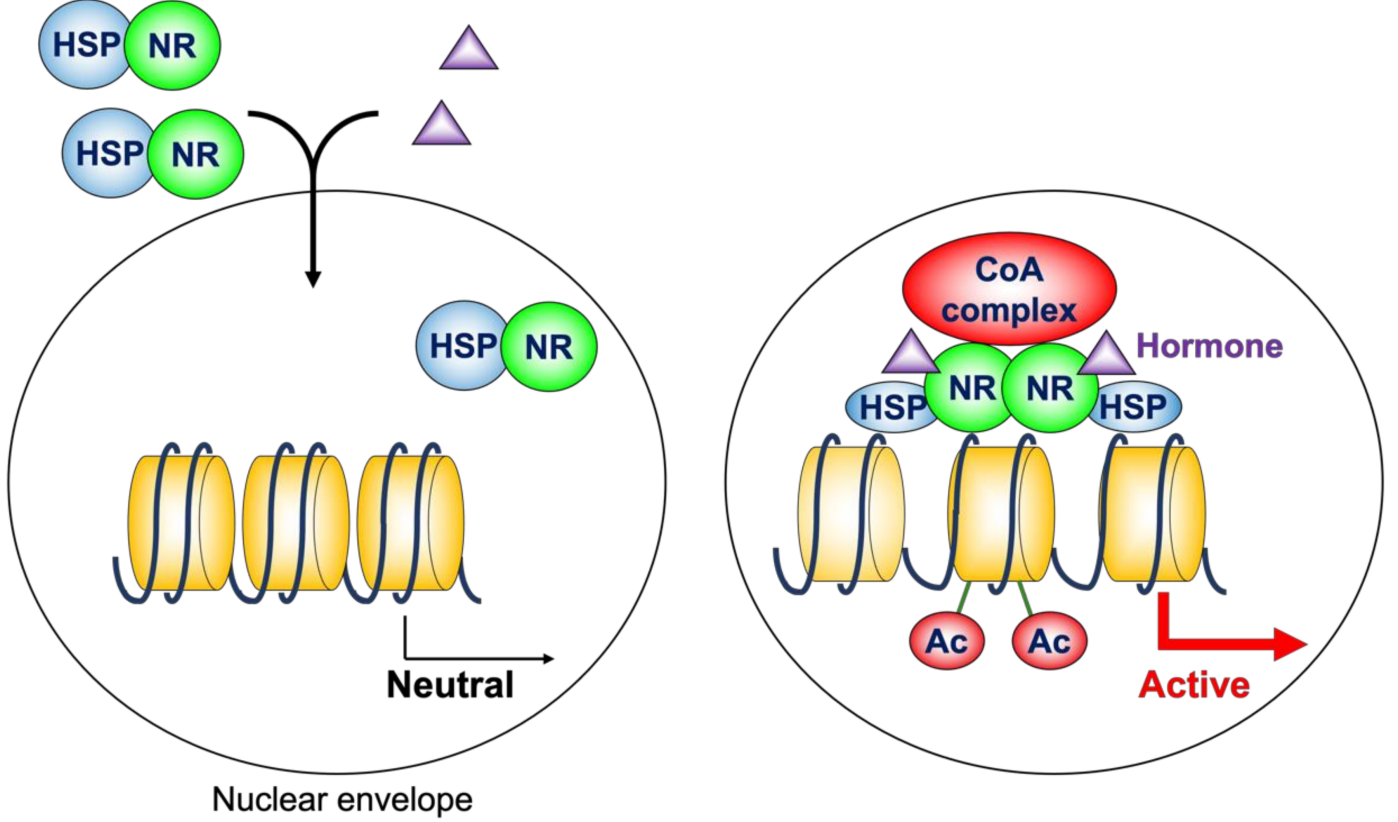

(b)

Figure 1. (a) Cofactor exchange by heterodimeric nuclear hormone receptors. In the absence of ligands, these NRs are associated with corepressor complexes that possess HDAC activity and suppress the transcription of the target genes, which is called ligand-independent repression. When the ligands are present, corepressors dissociate, and coactivators are recruited instead. Many of these coactivators possess HAT activity. (b) Molecular action of homodimeric nuclear hormone receptors. In the absence of ligands, they bind to chaperone molecules, such as HSP 90 and HSP 70 in the cytosol. In addition, unliganded ER is also localized to the nucleus, but does not bind its target genes. Upon binding to the ligands, NRs enter nuclei, bind DNA, and stimulate transcription in association with coactivators. HSPs play important roles in nuclear translocation of NRs and transcriptional activity of liganded NRs. CoR, corepressor; CoA, coactivator; NR, nuclear hormone receptor; RXR, retinoid X receptor; Ac, acetylation; HSP, heat shock protein. 


\subsection{Homodimeric Nuclear Hormone Receptors}

The typical homodimerization NRs include the estrogen receptor (ER), the progesterone receptor (PR), the androgen receptor (AR), the glucocorticoid receptor (GR), and the mineralocorticoid receptor (MR). These NRs have relatively large $\mathrm{N}$-terminal domains. They were previously called "type $1 \mathrm{NRs}$ " [26], which is no longer a common term. In the absence of ligands, they bind to chaperone molecules, such as heat shock protein (HSP) 90 and HSP 70 in the cytosol $[26,44]$. In addition, unliganded ER is also localized to the nucleus, but does not bind its target genes [45]. Therefore, these NREs do not directly regulate gene transcription in the unliganded state. Upon binding to the ligands, NRs bind DNA, and stimulate transcription in association with coactivators (Figure 1b). The conformational change by the "mousetrap" mechanism [42] is responsible for the interaction with coactivators. In the traditional model, it was believed that HSPs dissociate from NRs and remain in the cytosol. However, recently it was shown that HSPs play an important role in the nuclear translocation of NRs $[45,46]$. Moreover, HSPs in the nuclei contribute to the transcriptional activity of liganded NRs [47]. In this model, the role of corepressors with HDAC activity is limited.

\subsection{Orphan Nuclear Hormone Receptors}

In addition to these NRs, there are multiple orphan NRs whose ligands are yet to be identified [48]. These NRs serve as transcription factors and regulate gene transcription. Whereas some of them activate transcription of the target genes in cooperation with coactivators, others serve as transcriptional repressors by interacting with corepressors. Orphan NRs are attractive therapeutic targets of diseases because of their important roles and high specificities for their target genes. Many efforts are underway to identify natural or synthetic ligands for several orphan NRs.

\section{Histone Deacetylase 3 in Nuclear Hormone Receptor Corepressor Complex \\ 3.1. Basics of Histone Deacetylase 3}

Although acetylation of histones has been extensively studied, histones are not the only substrates for acetylation and deacetylation. Given the importance of acetylation of non-histone proteins, HDACs have been renamed to lysine deacetylases (KDACs) [49,50]. Similarly, HATs are officially called lysine acetyltransferases (KATs). However, the familiar name "HDAC" will be used in this review.

Since the discovery of HDAC1 [20], at least 18 potential HDACs have been reported in humans. Based on their sequence similarity, human HDACs are categorized into four classes [51]. Class I HDACs are similar to yeast Rpd3, and include HDAC1, 2, 3, and 8. The members of class II HDACs include HDAC4, 5, 6, 7, 9, and 10, and are homologous to yeast Hda1. Unlike other classes, the activity of class III HDACs is dependent on nicotinamide adenine dinucleotide $\left(\mathrm{NAD}^{+}\right)$. Class III HDACs show similarities to yeast Sir2, and include SIRT1, 2, 3, 4, 5, 6, and 7. HDAC11 is categorized as class IV because the sequence in the catalytic domain is unique.

HDAC3 was initially reported soon after HDAC1 [52-54]. HDAC3 consists of 428 amino acids, and the theoretical molecular weight is $49 \mathrm{kDa}$. It is ubiquitously expressed in many cell lines and tissues. HDAC3 does not directly bind to DNA or NRs. Bhaskara et al. reported that HDAC3-knockout mice were embryonic lethal, and that HDAC3-deficient embryonic fibroblasts exhibited a delay in cell cycle progression, cell cycle-dependent DNA damage, and apoptosis [55]. Indeed, HDAC3 plays pivotal roles in maintaining basic properties of cells, including Aurora B kinase activity in mitosis [56]; mitotic kinetochore-microtubule attachment [57]; sister chromatid cohesion [58]; maintenance of chromatin structure and genome stability [59]; DNA replication in hematopoietic progenitor cells [60]; and gap 2/mitosis progression [61]. 


\subsection{Histone Deacetylase 3 and Nuclear Hormone Receptor Corepressors}

HDAC3 was implicated in nuclear hormone receptor action by the identification of its core interaction partners in the early 21st century. Biochemical purification of HDAC3associated protein complex revealed that N-CoR and SMRT are the members of the HDAC3 core complex [62,63]. Reciprocally, N-CoR and SMRT form a stable complex with HDAC3, but not with other HDACs [63-66]. These findings were surprising because many researchers expected that well-known HDAC1 and 2 would play a major role; however, these findings were confirmed because the same results were reported by several independent laboratories. Currently, it is established that HDAC3 core complex is distinct from HDAC $1 / 2$ core complex, which contains RbAp46 and RbAp48. These facts indicate that HDAC3 is the main HDAC responsible for the ligand-independent repression by NRs, because both N-CoR and SMRT are the major mediators of repression, but do not exhibit deacetylase activity by themselves. On the other hand, HDAC3 does not directly bind NRs. $\mathrm{N}-\mathrm{CoR}$ and SMRT tether HDAC3 to transcriptional repressors, like unliganded NRs.

Moreover, interaction with N-CoR/SMRT substantially potentiates the enzymatic activity of HDAC3. The deacetylase activating domain (DAD) is determined for both $\mathrm{N}$ CoR and SMRT [67]. The DADs in the corepressors are also responsible for the interaction with HDAC3, and contain SANT motifs, which contribute to histone binding in other proteins. Analyses of the crystal structure of DAD-HDAC3 complex revealed that inositol tetraphosphate is necessary for the interaction [68]. An introduction of mutations that abolish HDAC3 interaction in both N-CoR and SMRT results in a loss of deacetylase activity in vivo [69]. Indeed, integration of HDAC3 into N-CoR/SMRT complex is important for the ligand-independent repression by NRs [70]. One of the additional factors that regulate enzymatic activity is phosphorylation of HDAC3. Casein kinase 2 and protein serine/threonine phosphatase 4 complex are involved in this regulation [71].

Other HDAC 3 core complex members include transducin beta-like $1 \mathrm{X}$-linked (TBL1X), TBL1X receptor 1 (TBL1XR1), and G protein pathway suppressor 2 (GPS2). These molecules also play important roles in the functions of the corepressor complex [72]. Both TBL1X and TBL1XR1 are WD40 repeat-containing proteins. Suggested roles of these molecules in $\mathrm{N}-\mathrm{CoR} / \mathrm{SMRT}$ complex include histone binding [73] and degradation of the corepressor complex via the ubiquitin-proteasome pathway [74]. Mutations in the TBL1X gene are associated with central hypothyroidism [75], although the mechanism is not clarified yet. GPS2 is responsible for the inhibition of the JNK pathway by HDAC3 complex [63]. On the other hand, it was reported that phosphorylation of c-Jun, an AP-1 transcription factor subunit, by JNK pathway dissociates HDAC3 complex from c-Jun and relieves transcriptional repression [76].

\subsection{Physiological Roles of Histone Deacetylase 3}

Tissue-specific functions of HDAC 3 have been studied using cell-type specific knockout mice [77], because conventional knockout mice are embryonic lethal [55,78]. For example, HDAC3 is involved in energy metabolism and organogenesis of the heart [78-80]. Liverspecific knockout mice revealed the roles of HDAC3 in lipid metabolism and circadian rhythm [81-83]. HDAC3 is also involved in the alternative activation of the macrophages [84]. HDAC3 in intestinal epithelial cells contributes to local lymphocyte activation [85]. The roles in bone formation [86,87], brain organogenesis [88], and lung development [89] are documented. Furthermore, HDAC3 regulates thermogenic gene transcription in brown adipose tissue [90], insulin sensitivity in muscles [91], and insulin secretion [92]. However, there is no report of human diseases caused by a germline mutation of HDAC3 gene so far. This is probably because these mutations result in embryonic lethality. 
In addition, it is suggested that HDAC3 is involved in cancer progression. Overexpression of HDAC 3 is observed in many types of cancers, particularly leukemia and lymphoma [93]. Moreover, several broad-spectrum HDAC inhibitors have been approved by the FDA as therapeutic agents for the treatment of particular types of lymphomas [94]. Therefore, specific inhibition of HDAC 3 is an attractive therapeutic strategy for the treatment of malignant diseases [93].

\section{Histone Deacetylase 3 in Nuclear Hormone Receptor Action}

\subsection{Ligand-Independent Repression}

As mentioned above, a heterodimeric group of NRs, including TR, RAR, and VDR, is associated with N-CoR/SMRT complexes that contain HDAC3 and suppress the transcription of the target genes in the absence of a ligand. On the other hand, the homodimerization NRs, including ER, PR, GR, MR, and AR, are "neutral" in terms of gene expression without ligands, because these NRs do not bind their target genes in the unliganded state. It seems that the importance of the difference between these two groups is not as highly evaluated as before. However, it is a notable point when considering the function of N-CoR/SMRT and HDAC3.

The findings show the importance of ligand-independent repression by the heterodimeric NRs, including its role in phenotypic expression of TR-knockout mice and hypothyroid mice. The defects are much more severe in hypothyroid mice than in TRdeficient mice, indicating the roles of repression by unliganded TR $[95,96]$. As a core deacetylase component of N-CoR/SMRT complex, HDAC3 plays a critical role in ligandindependent repression by deacetylating histone tails (Figure 2a). Indeed, it has been reported that HDAC3 is involved in the repressive functions of unliganded TR $[65,97,98]$, RAR [99], and VDR [100]. In addition to these reports, the role of N-CoR/SMRT in the ligand-independent repression are extensively studied in numerous cases. Although the involvement of HDAC 3 is not directly examined, it is expected that HDAC3 is the major player in these cases.

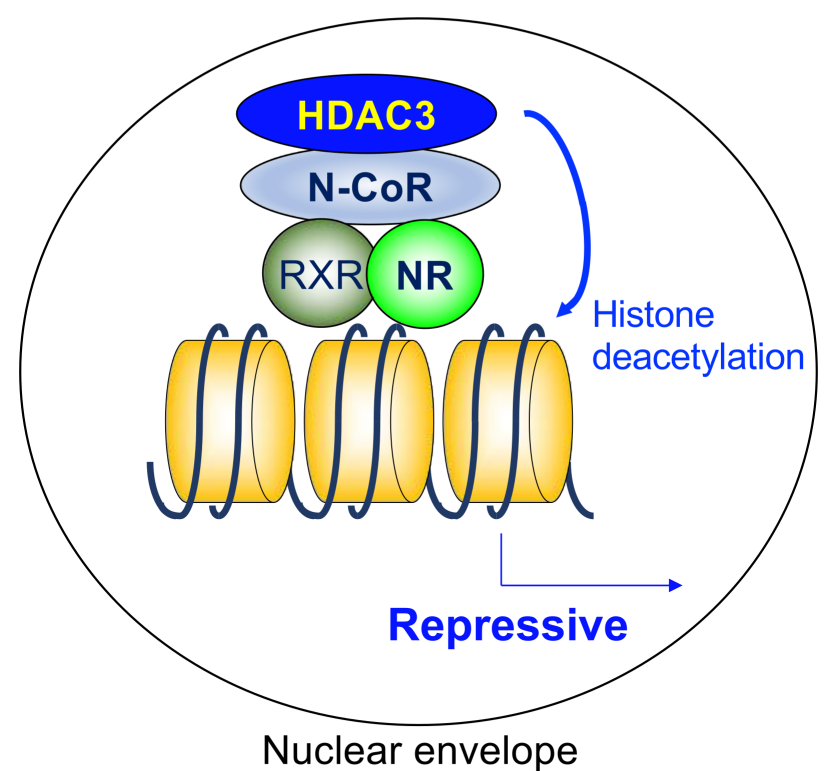

(a)

Figure 2. Cont. 

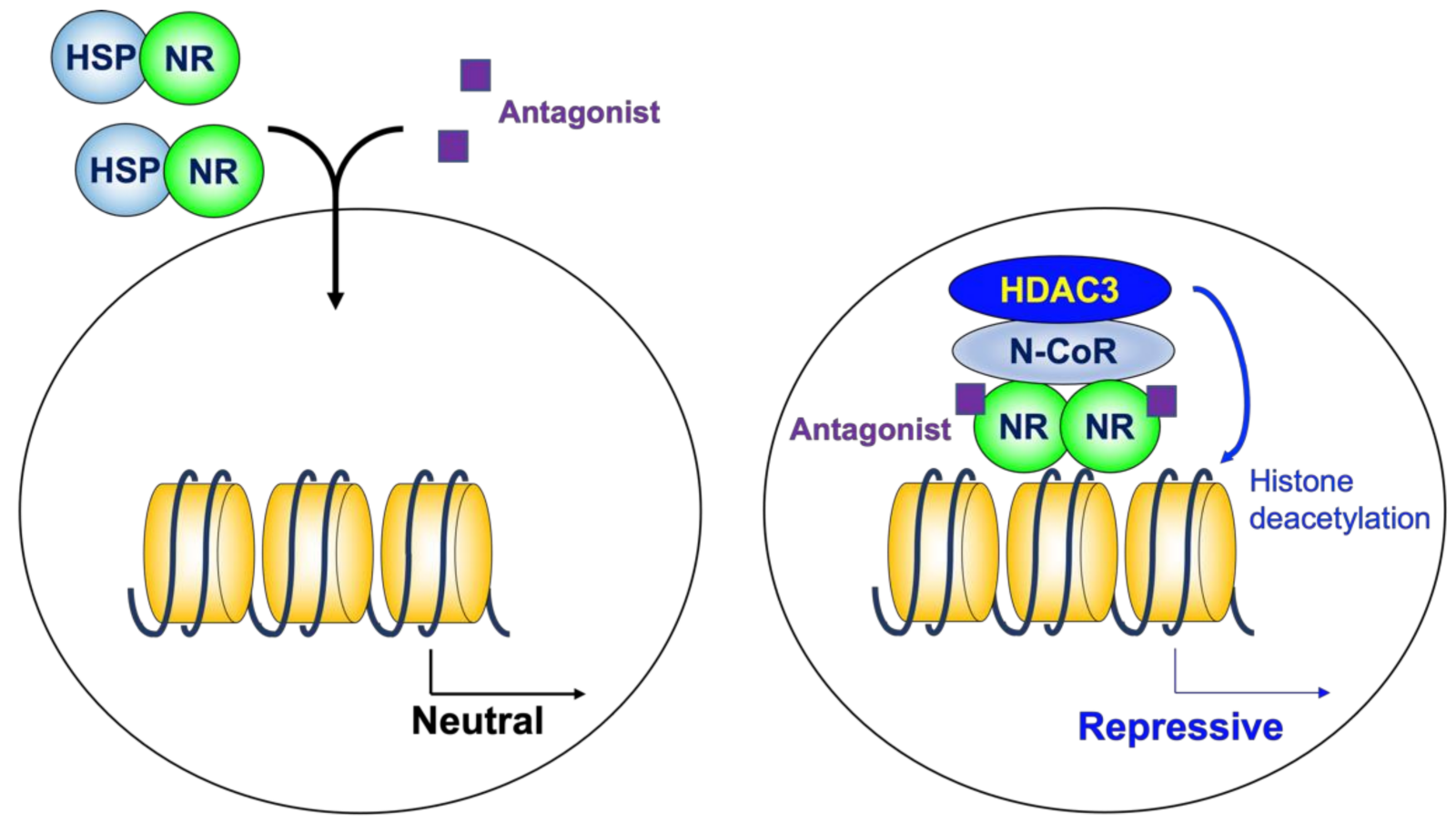

Nuclear envelope

(b)

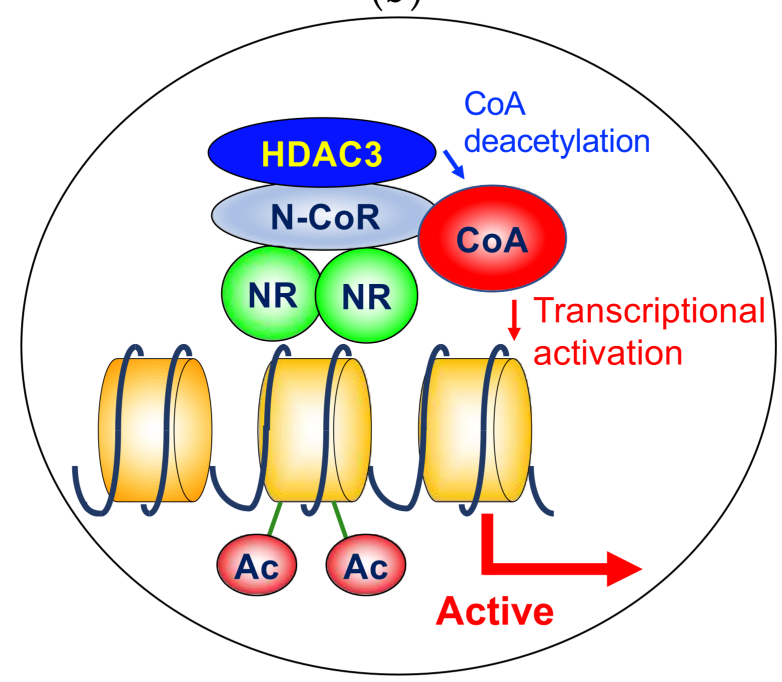

(c)

Figure 2. (a) Histone deacetylase 3 in ligand-independent repression. As a core deacetylase component of N-CoR/SMRT complex, HDAC3 plays a critical role in ligand-independent repression by deacetylating histone tails. (b) Histone deacetylase 3 in antagonist-induced repression. Some antagonists for homodimeric NRs induce gene repression in coordination with the HDAC3 complex. (c) Histone deacetylase 3 activates a transcriptional coactivator by deacetylation. The activated coactivators stimulate transcription on the target genes. HDAC3, histone deacetylase 3; N-CoR, nuclear receptor corepressor; $\mathrm{NR}$, nuclear hormone receptor; RXR, retinoid X receptor; HSP, heat shock protein; CoA, coactivator.

RAR $\alpha$ is involved in the etiology of acute promyelocytic leukemia (APL), in which leukocyte differentiation is blocked at the promyelocyte stage. Retinoic acid plays important roles in the differentiation of many types of cells, including granulocytes. The majority of APL cases are caused by chromosomal translocations that produce a promyelocytic leukemia (PML)-RAR alpha (RARA) fusion protein [101]. PML-RARA disrupts both PML nuclear body assembly and RAR-dependent transcription [102]. The fusion 
protein competes with wild-type RAR in a dominant-negative manner and suppresses the transcription of retinoic acid-dependent differentiation genes. The PML-RARA protein is associated with N-CoR/SMRT complex like unliganded RAR, and HDAC3 is involved in the gene repression as the main HDAC [103-105]. Treatment with supraphysiological doses of all-trans retinoic acid dissociates N-CoR/SMRT-HDAC3 complex from the fusion protein and induces gene expression and differentiation of the tumor cells. Retinoic acid also enhances the formation of PML nuclear body assembly, which is also potentiated by treatment with arsenic trioxide.

\subsection{Gene Repression by Orphan Nuclear Hormone Receptors}

Gene expression is suppressed by several orphan NRs, whose ligands have not yet been identified. These NRs work as monomers, homodimers, or heterodimers with RXR or other NRs [48]. The typical molecular mechanism is similar to ligand-independent repression, where histone deacetylation by N-CoR/SMRT-HDAC3 complex plays a pivotal role.

An orphan NR, REV-ERB $\alpha$, was initially identified as a molecule whose gene is encoded by the reverse strand of the $c$-erbA $\alpha$ oncogene [106]. Later, it appeared that the $c$-erbA $\alpha$ oncogene encodes TR $\alpha[107,108]$. REV-ERB $\alpha$ works as a transcriptional repressor in coordination with the N-CoR complex. REV-ERB $\alpha$ plays a central role in circadian rhythm by repressing core clock genes, including BMAL1. The critical involvement of HDAC3 was reported on a genome-wide scale [109].

Regarding other orphan NRs, HDAC3 is also involved in lineage restriction of embryonic stem cells mediated by dosage-sensitive sex reversal, adrenal hypoplasia critical region, chromosome $X$, gene 1 (DAX1) [110], TR2-mediated gene repression [111], and neural stem cell proliferation by TLX [112]. Although direct evidence is still missing, other repressive orphan NRs are speculated to cooperate with HDAC3, because some of them are associated with N-CoR/SMRT [113].

\subsection{Nuclear Hormone Receptor Antagonist Action}

As shown in Figure 1b, a homodimeric group of NRs is not associated with the target genes in the absence of a ligand. The HDAC3 complex is not directly involved in that model; however, some antagonists for these NRs induce gene repression in coordination with the corepressor complex, including HDAC3 (Figure 2b).

Some of the most extensively studied NR antagonists are the modulators of ER function used in the treatment of hormone-sensitive breast cancer [114]. Selective estrogen receptor modulators, such as tamoxifen and raloxifene, show antagonistic effects, at least to some extent [115]. HDAC3 in the N-CoR/SMRT complex is involved in tamoxifenmediated gene repression [116]. In contrast, the role of N-CoR/SMRT-HDAC3 complex in the treatment of hormone-sensitive prostate cancer with selective androgen receptor modulators is not supported so far [117].

\subsection{Ligand-Induced Repression}

Typical NR agonists stimulate the transcription of the target genes, as mentioned above. However, a certain number of genes are suppressed in the presence of hormones. It is hard to explain the molecular mechanism behind this because liganded NRs bind coactivators rather than corepressors due to their structures [42]. Although some reports suggest the role of HDAC3 in ligand-induced repression [118,119], a common mechanism that explains all ligand-dependent repression cases is yet to be described.

\subsection{Activation of Transcriptional Coactivator by Histone Deacetylase 3}

Although histone deacetylation is highly associated with gene repression, there are several genes activated by HDAC3 via NRs. At least some cases are explained by deacetylation of non-histone proteins [50]. One convincing example is the role of HDAC3 in transcriptional stimulation in brown adipose tissue [90]. In this model, the N-CoR/SMRTHDAC3 complex is tethered to chromatin by the first identified orphan nuclear hormone 
receptor, the estrogen-related receptor- $\alpha(E R R \alpha)$ [120]. ERR $\alpha$ plays an essential role in adaptive thermogenesis by enhancing the transcription of thermogenic genes [121]. Peroxisome proliferator-activated receptor- $\gamma$ coactivator $1 \alpha(\mathrm{PGC} 1 \alpha)$ is an essential coactivator for ERR $\alpha$ [122], and the function of PGC1 $\alpha$ is inhibited by acetylation [123]. A class III HDACs SIRT1 is a known HDAC that deacetylates and activates PGC1 $\alpha$ [124]. In addition, Emmett et al. reported that HDAC3 stimulates thermogenic gene expression by deacetylating PGC1 $\alpha$ (Figure 2c) [90].

\section{Non-Canonical Mechanisms of Histone Deacetylase 3 Action for Other Transcription Factors}

Although the responsible transcription factors are unknown or are not NRs, noncanonical mechanisms of HDAC3 action are reported. These mechanisms might be involved in NR action as well.

For example, several functions that are independent of the enzymatic activity of HDAC3 were studied. HDAC3 tethers target genes to the peripheral region of nuclei by interacting with the nuclear lamina protein lamina-associated polypeptide $2[80,125]$. HDAC3 recruits polycomb repressive complex 2, which possesses histone methyltransferase activity, independently of HDAC activity [126]. In addition, HDAC3 is recruited to activate transcription factor 2-bound sites without association with N-CoR/SMRT, and activates the expression of inflammatory genes [127].

Many findings of acetylation/deacetylation of non-histone proteins are emerging as novel and important aspects of posttranslational modifications [49,50]. Several nonhistone substrates are reported for HDAC3. For instance, p65, a subunit of nuclear factor kappa-B (NF-kB), is deacetylated by HDAC3. Deacetylation results in stimulation or suppression of NF- $\kappa B$-dependent transcription, depending on the acetylation sites [128,129]. Sex-determining region $\mathrm{Y}(\mathrm{SRY})$, a key transcription factor for the determination of testis differentiation, also undergoes deacetylation by HDAC3 and subsequent nuclear export [130].

In addition, HDAC3 does not localize only in nuclei. It is also identified in the cytoplasm of several cell lines, including DT40 [131], 293 [132], mouse embryonic fibroblasts [133], 3T3-L1 [133], and PC3 [134]. The cytosolic function of HDAC3 is still under investigation.

\section{Conclusions and Perspectives}

As the core HDAC component of the N-CoR/SMRT corepressor complex, HDAC3 is largely responsible for transcriptional repression mediated by NRs and other transcription factors. The HDAC3 complex mainly suppresses transcription by deacetylating histones.

On the other hand, recently the roles of HDAC3, independent of its enzymatic activity, are reported for transcription factors other than NRs, as mentioned above. In addition, nonhistone proteins are of interest as novel substrates for HDAC3. These tendencies suggest that non-canonical mechanisms of HDAC3 in NR action will be a hot topic in the near future. Moreover, HDAC3 is also localized in the cytosol. Therefore, it would not be surprising if cytosolic NR-HDAC3 complex exerts some transcription-independent functions.

Funding: This research was funded by JSPS KAKENHI Grant No. 21K08569.

Institutional Review Board Statement: Not applicable.

Informed Consent Statement: Not applicable.

Data Availability Statement: No new data were created or analyzed in this study. Data sharing is not applicable to this article.

Conflicts of Interest: The author declares no conflict of interest. 


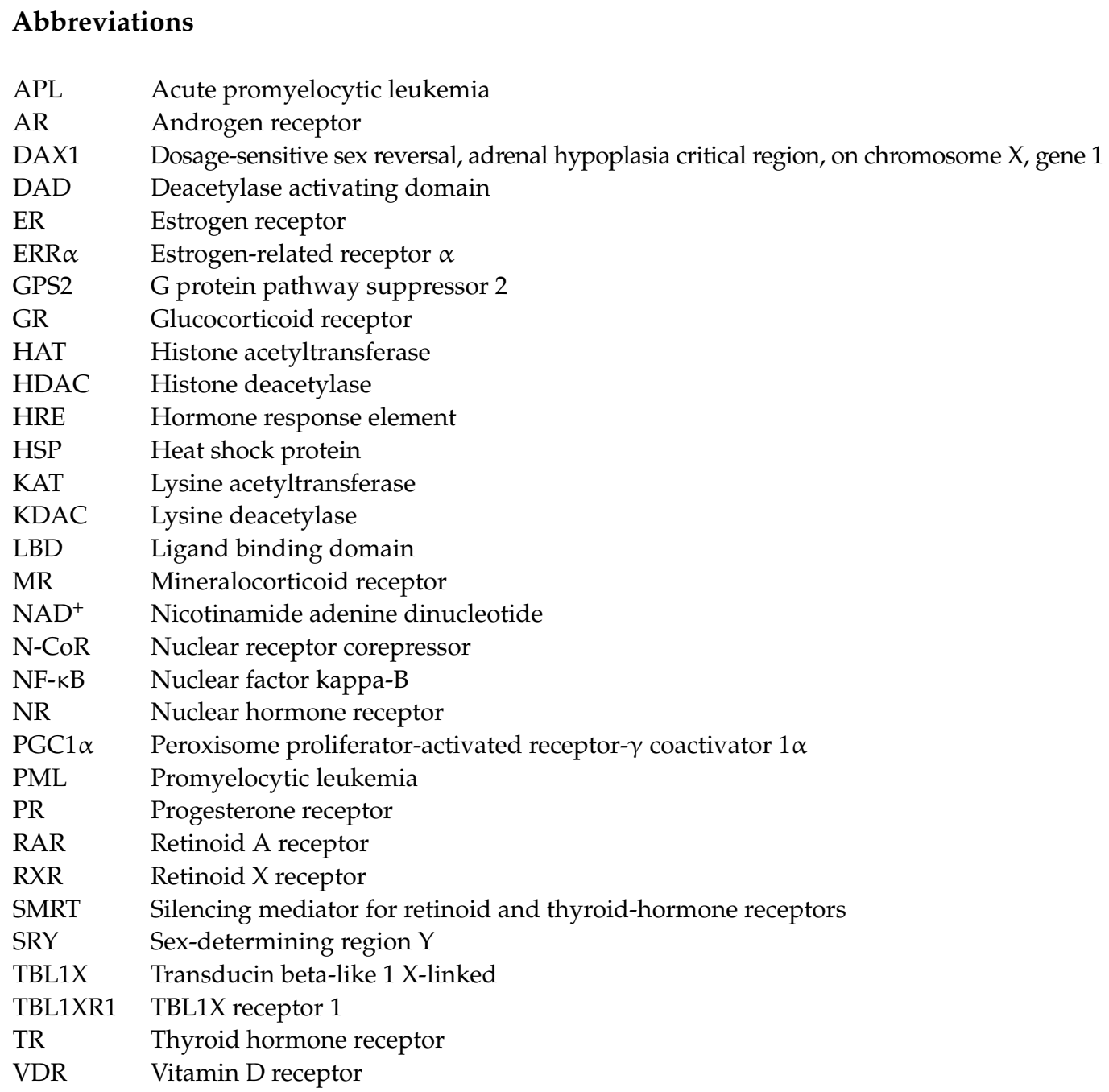

\section{References}

1. Dumitrescu, A.M.; Liao, X.H.; Best, T.B.; Brockmann, K.; Refetoff, S. A novel syndrome combining thyroid and neurological abnormalities is associated with mutations in a monocarboxylate transporter gene. Am. J. Hum. Genet. 2004, 74, 168-175. [CrossRef] [PubMed]

2. Rosen, E.D.; Carter-SU, C. Principles of Hormone Action. In Williams Textbook of Endocrinology, 14th ed.; Melmed, S., Auchus, R.J., Goldfine, A.B., Koenig, R.J., Rosen, C.J., Eds.; Elsevir: Philadelphia, PA, USA, 2020; pp. 13-41.

3. Mangelsdorf, D.J.; Thummel, C.; Beato, M.; Herrlich, P.; Schütz, G.; Umesono, K.; Blumberg, B.; Kastner, P.; Mark, M.; Chambon, P.; et al. The nuclear receptor superfamily: The second decade. Cell 1995, 83, 835-839. [CrossRef]

4. Committee, N.R.N. A unified nomenclature system for the nuclear receptor superfamily. Cell 1999, 97, 161-163. [CrossRef]

5. Krust, A.; Green, S.; Argos, P.; Kumar, V.; Walter, P.; Bornert, J.M.; Chambon, P. The chicken oestrogen receptor sequence: Homology with v-erbA and the human oestrogen and glucocorticoid receptors. EMBO J. 1986, 5, 891-897. [CrossRef] [PubMed]

6. Huang, P.; Chandra, V.; Rastinejad, F. Structural overview of the nuclear receptor superfamily: Insights into physiology and therapeutics. Annu. Rev. Physiol. 2010, 72, 247-272. [CrossRef] [PubMed]

7. Berg, J.M. DNA binding specificity of steroid receptors. Cell 1989, 57, 1065-1068. [CrossRef]

8. Gronemeyer, H.; Moras, D. Nuclear receptors. How to finger DNA. Nature 1995, 375, 190-191. [CrossRef] [PubMed]

9. Tora, L.; White, J.; Brou, C.; Tasset, D.; Webster, N.; Scheer, E.; Chambon, P. The human estrogen receptor has two independent nonacidic transcriptional activation functions. Cell 1989, 59, 477-487. [CrossRef]

10. Bourguet, W.; Ruff, M.; Chambon, P.; Gronemeyer, H.; Moras, D. Crystal structure of the ligand-binding domain of the human nuclear receptor RXR-alpha. Nature 1995, 375, 377-382. [CrossRef]

11. Moras, D.; Gronemeyer, H. The nuclear receptor ligand-binding domain: Structure and function. Curr. Opin. Cell Biol. 1998, 10, 384-391. [CrossRef]

12. Lonard, D.M.; O'Malley, B.W. Nuclear receptor coregulators: Modulators of pathology and therapeutic targets. Nat. Rev. Endocrinol. 2012, 8, 598-604. [CrossRef]

13. Jenuwein, T.; Allis, C.D. Translating the histone code. Science 2001, 293, 1074-1080. [CrossRef] [PubMed] 
14. Li, B.; Carey, M.; Workman, J.L. The role of chromatin during transcription. Cell 2007, 128, 707-719. [CrossRef] [PubMed]

15. Allfrey, V.G.; Faulkner, R.; Mirsky, A.E. Acetylation and Methylation of Histones and Their Possible Role in the Regulation of RNA Synthesis. Proc. Natl. Acad. Sci. USA 1964, 51, 786-794. [CrossRef]

16. Grunstein, M. Histone acetylation in chromatin structure and transcription. Nature 1997, 389, 349-352. [CrossRef]

17. Verdin, E.; Ott, M. 50 years of protein acetylation: From gene regulation to epigenetics, metabolism and beyond. Nat. Rev. Mol. Cell. Biol. 2015, 16, 258-264. [CrossRef] [PubMed]

18. Brownell, J.E.; Zhou, J.; Ranalli, T.; Kobayashi, R.; Edmondson, D.G.; Roth, S.Y.; Allis, C.D. Tetrahymena histone acetyltransferase A: A homolog to yeast Gcn5p linking histone acetylation to gene activation. Cell 1996, 84, 843-851. [CrossRef]

19. Sterner, D.E.; Berger, S.L. Acetylation of histones and transcription-related factors. Microbiol. Mol. Biol. Rev. 2000, 64, 435-459. [CrossRef] [PubMed]

20. Taunton, J.; Hassig, C.A.; Schreiber, S.L. A mammalian histone deacetylase related to the yeast transcriptional regulator Rpd3p. Science 1996, 272, 408-411. [CrossRef] [PubMed]

21. Ng, H.H.; Bird, A. Histone deacetylases: Silencers for hire. Trends Biochem. Sci. 2000, 25, 121-126. [CrossRef]

22. Xu, F.; Zhang, K.; Grunstein, M. Acetylation in histone H3 globular domain regulates gene expression in yeast. Cell 2005, 121, 375-385. [CrossRef]

23. Lawrence, M.; Daujat, S.; Schneider, R. Lateral Thinking: How Histone Modifications Regulate Gene Expression. Trends Genet. 2016, 32, 42-56. [CrossRef] [PubMed]

24. Dall'Olio, F.; Trinchera, M. Epigenetic Bases of Aberrant Glycosylation in Cancer. Int. J. Mol. Sci. 2017, 18, 998. [CrossRef] [PubMed]

25. Glass, C.K. Differential recognition of target genes by nuclear receptor monomers, dimers, and heterodimers. Endocr. Rev. 1994, 15, 391-407. [CrossRef] [PubMed]

26. Yen, P.M. Classical nuclear hormone receptor activity as a mediator of complex biological responses: A look at health and disease. Best Pract. Res. Clin. Endocrinol. Metab. 2015, 29, 517-528. [CrossRef]

27. Baniahmad, A.; Steiner, C.; Köhne, A.C.; Renkawitz, R. Modular structure of a chicken lysozyme silencer: Involvement of an unusual thyroid hormone receptor binding site. Cell 1990, 61, 505-514. [CrossRef]

28. Burcin, M.; Köhne, A.C.; Runge, D.; Steiner, C.; Renkawitz, R. Factors influencing nuclear receptors in transcriptional repression. Semin. Cancer Biol. 1994, 5, 337-346. [PubMed]

29. Hu, X.; Lazar, M.A. Transcriptional repression by nuclear hormone receptors. Trends Endocrinol. Metab. 2000, 11, 6-10. [CrossRef]

30. Hörlein, A.J.; Näär, A.M.; Heinzel, T.; Torchia, J.; Gloss, B.; Kurokawa, R.; Ryan, A.; Kamei, Y.; Söderström, M.; Glass, C.K. Ligand-independent repression by the thyroid hormone receptor mediated by a nuclear receptor co-repressor. Nature 1995, 377, 397-404. [CrossRef]

31. Chen, J.D.; Evans, R.M. A transcriptional co-repressor that interacts with nuclear hormone receptors. Nature 1995, 377, 454-457. [CrossRef]

32. Jepsen, K.; Hermanson, O.; Onami, T.M.; Gleiberman, A.S.; Lunyak, V.; McEvilly, R.J.; Kurokawa, R.; Kumar, V.; Liu, F.; Seto, E.; et al. Combinatorial roles of the nuclear receptor corepressor in transcription and development. Cell 2000, 102, 753-763. [CrossRef]

33. Jepsen, K.; Solum, D.; Zhou, T.; McEvilly, R.J.; Kim, H.J.; Glass, C.K.; Hermanson, O.; Rosenfeld, M.G. SMRT-mediated repression of an H3K27 demethylase in progression from neural stem cell to neuron. Nature 2007, 450, 415-419. [CrossRef] [PubMed]

34. Glass, C.K.; Rosenfeld, M.G. The coregulator exchange in transcriptional functions of nuclear receptors. Genes Dev. 2000, 14, 121-141. [PubMed]

35. Perissi, V.; Jepsen, K.; Glass, C.K.; Rosenfeld, M.G. Deconstructing repression: Evolving models of co-repressor action. Nat. Rev. Genet. 2010, 11, 109-123. [CrossRef] [PubMed]

36. Cavaillès, V.; Dauvois, S.; Danielian, P.S.; Parker, M.G. Interaction of proteins with transcriptionally active estrogen receptors. Proc. Natl. Acad. Sci. USA 1994, 91, 10009-10013. [CrossRef] [PubMed]

37. Oñate, S.A.; Tsai, S.Y.; Tsai, M.J.; O'Malley, B.W. Sequence and characterization of a coactivator for the steroid hormone receptor superfamily. Science 1995, 270, 1354-1357. [CrossRef]

38. Hong, H.; Kohli, K.; Garabedian, M.J.; Stallcup, M.R. GRIP1, a transcriptional coactivator for the AF-2 transactivation domain of steroid, thyroid, retinoid, and vitamin D receptors. Mol. Cell. Biol. 1997, 17, 2735-2744. [CrossRef]

39. Anzick, S.L.; Kononen, J.; Walker, R.L.; Azorsa, D.O.; Tanner, M.M.; Guan, X.Y.; Sauter, G.; Kallioniemi, O.P.; Trent, J.M.; Meltzer, P.S. AIB1, a steroid receptor coactivator amplified in breast and ovarian cancer. Science 1997, 277, 965-968. [CrossRef] [PubMed]

40. Kamei, Y.; Xu, L.; Heinzel, T.; Torchia, J.; Kurokawa, R.; Gloss, B.; Lin, S.C.; Heyman, R.A.; Rose, D.W.; Glass, C.K.; et al. A CBP integrator complex mediates transcriptional activation and AP-1 inhibition by nuclear receptors. Cell 1996, 85, $403-414$. [CrossRef]

41. Torchia, J.; Rose, D.W.; Inostroza, J.; Kamei, Y.; Westin, S.; Glass, C.K.; Rosenfeld, M.G. The transcriptional co-activator p/CIP binds CBP and mediates nuclear-receptor function. Nature 1997, 387, 677-684. [CrossRef]

42. Renaud, J.P.; Rochel, N.; Ruff, M.; Vivat, V.; Chambon, P.; Gronemeyer, H.; Moras, D. Crystal structure of the RAR-gamma ligand-binding domain bound to all-trans retinoic acid. Nature 1995, 378, 681-689. [CrossRef]

43. Shabtai, Y.; Nagaraj, N.K.; Batmanov, K.; Cho, Y.W.; Guan, Y.; Jiang, C.; Remsberg, J.; Forrest, D.; Lazar, M.A. A coregulator shift, rather than the canonical switch, underlies thyroid hormone action in the liver. Genes Dev. 2021, 35, 367-378. [CrossRef] 
44. Pratt, W.B.; Toft, D.O. Steroid receptor interactions with heat shock protein and immunophilin chaperones. Endocr. Rev. 1997, 18, 306-360. [CrossRef]

45. Leclercq, G.; Lacroix, M.; Laïos, I.; Laurent, G. Estrogen receptor alpha: Impact of ligands on intracellular shuttling and turnover rate in breast cancer cells. Curr. Cancer Drug Targets 2006, 6, 39-64. [CrossRef] [PubMed]

46. Elbi, C.; Walker, D.A.; Romero, G.; Sullivan, W.P.; Toft, D.O.; Hager, G.L.; DeFranco, D.B. Molecular chaperones function as steroid receptor nuclear mobility factors. Proc. Natl. Acad. Sci. USA 2004, 101, 2876-2881. [CrossRef]

47. Xin, Q.L.; Qiu, J.T.; Cui, S.; Xia, G.L.; Wang, H.B. Transcriptional activation of nuclear estrogen receptor and progesterone receptor and its regulation. Sheng Li Xue Bao 2016, 68, 435-454.

48. Mullican, S.E.; Dispirito, J.R.; Lazar, M.A. The orphan nuclear receptors at their 25-year reunion. J. Mol. Endocrinol. 2013, 51, T115-T140. [CrossRef] [PubMed]

49. Gu, W.; Roeder, R.G. Activation of p53 sequence-specific DNA binding by acetylation of the p53 C-terminal domain. Cell 1997, 90, 595-606. [CrossRef]

50. Narita, T.; Weinert, B.T.; Choudhary, C. Functions and mechanisms of non-histone protein acetylation. Nat. Rev. Mol. Cell. Biol. 2019, 20, 156-174. [CrossRef]

51. Seto, E.; Yoshida, M. Erasers of histone acetylation: The histone deacetylase enzymes. Cold Spring Harb. Perspect Biol. 2014, 6, a018713. [CrossRef] [PubMed]

52. Yang, W.M.; Yao, Y.L.; Sun, J.M.; Davie, J.R.; Seto, E. Isolation and characterization of cDNAs corresponding to an additional member of the human histone deacetylase gene family. J. Biol. Chem. 1997, 272, 28001-28007. [CrossRef]

53. Emiliani, S.; Fischle, W.; Van Lint, C.; Al-Abed, Y.; Verdin, E. Characterization of a human RPD3 ortholog, HDAC3. Proc. Natl. Acad. Sci. USA 1998, 95, 2795-2800. [CrossRef]

54. Dangond, F.; Hafler, D.A.; Tong, J.K.; Randall, J.; Kojima, R.; Utku, N.; Gullans, S.R. Differential display cloning of a novel human histone deacetylase (HDAC3) cDNA from PHA-activated immune cells. Biochem. Biophys. Res. Commun. 1998, 242, 648-652. [CrossRef]

55. Bhaskara, S.; Chyla, B.J.; Amann, J.M.; Knutson, S.K.; Cortez, D.; Sun, Z.W.; Hiebert, S.W. Deletion of histone deacetylase 3 reveals critical roles in S phase progression and DNA damage control. Mol. Cell 2008, 30, 61-72. [CrossRef] [PubMed]

56. Li, Y.; Kao, G.D.; Garcia, B.A.; Shabanowitz, J.; Hunt, D.F.; Qin, J.; Phelan, C.; Lazar, M.A. A novel histone deacetylase pathway regulates mitosis by modulating Aurora B kinase activity. Genes Dev. 2006, 20, 2566-2579. [CrossRef] [PubMed]

57. Ishii, S.; Kurasawa, Y.; Wong, J.; Yu-Lee, L.Y. Histone deacetylase 3 localizes to the mitotic spindle and is required for kinetochoremicrotubule attachment. Proc. Natl. Acad. Sci. USA 2008, 105, 4179-4184. [CrossRef] [PubMed]

58. Eot-Houllier, G.; Fulcrand, G.; Watanabe, Y.; Magnaghi-Jaulin, L.; Jaulin, C. Histone deacetylase 3 is required for centromeric H3K4 deacetylation and sister chromatid cohesion. Genes Dev. 2008, 22, 2639-2644. [CrossRef] [PubMed]

59. Bhaskara, S.; Knutson, S.K.; Jiang, G.; Chandrasekharan, M.B.; Wilson, A.J.; Zheng, S.; Yenamandra, A.; Locke, K.; Yuan, J.L.; Bonine-Summers, A.R.; et al. Hdac3 is essential for the maintenance of chromatin structure and genome stability. Cancer Cell 2010, 18, 436-447. [CrossRef] [PubMed]

60. Summers, A.R.; Fischer, M.A.; Stengel, K.R.; Zhao, Y.; Kaiser, J.F.; Wells, C.E.; Hunt, A.; Bhaskara, S.; Luzwick, J.W.; Sampathi, S.; et al. HDAC3 is essential for DNA replication in hematopoietic progenitor cells. J. Clin. Investig. 2013, 123, 3112-3123. [CrossRef] [PubMed]

61. Jiang, Y.; Hsieh, J. HDAC3 controls gap 2/mitosis progression in adult neural stem/progenitor cells by regulating CDK1 levels. Proc. Natl. Acad. Sci. USA 2014, 111, 13541-13546. [CrossRef] [PubMed]

62. Wen, Y.D.; Perissi, V.; Staszewski, L.M.; Yang, W.M.; Krones, A.; Glass, C.K.; Rosenfeld, M.G.; Seto, E. The histone deacetylase-3 complex contains nuclear receptor corepressors. Proc. Natl. Acad. Sci. USA 2000, 97, 7202-7207. [CrossRef] [PubMed]

63. Zhang, J.; Kalkum, M.; Chait, B.T.; Roeder, R.G. The N-CoR-HDAC3 nuclear receptor corepressor complex inhibits the JNK pathway through the integral subunit GPS2. Mol. Cell 2002, 9, 611-623. [CrossRef]

64. Guenther, M.G.; Lane, W.S.; Fischle, W.; Verdin, E.; Lazar, M.A.; Shiekhattar, R. A core SMRT corepressor complex containing HDAC3 and TBL1, a WD40-repeat protein linked to deafness. Genes Dev. 2000, 14, 1048-1057. [PubMed]

65. Li, J.; Lin, Q.; Wang, W.; Wade, P.; Wong, J. Specific targeting and constitutive association of histone deacetylase complexes during transcriptional repression. Genes Dev. 2002, 16, 687-692. [CrossRef] [PubMed]

66. Yoon, H.G.; Chan, D.W.; Huang, Z.Q.; Li, J.; Fondell, J.D.; Qin, J.; Wong, J. Purification and functional characterization of the human N-CoR complex: The roles of HDAC3, TBL1 and TBLR1. EMBO J. 2003, 22, 1336-1346. [CrossRef]

67. Guenther, M.G.; Barak, O.; Lazar, M.A. The SMRT and N-CoR corepressors are activating cofactors for histone deacetylase 3. Mol. Cell. Biol. 2001, 21, 6091-6101. [CrossRef]

68. Watson, P.J.; Fairall, L.; Santos, G.M.; Schwabe, J.W. Structure of HDAC3 bound to co-repressor and inositol tetraphosphate. Nature 2012, 481, 335-340. [CrossRef]

69. You, S.H.; Lim, H.W.; Sun, Z.; Broache, M.; Won, K.J.; Lazar, M.A. Nuclear receptor co-repressors are required for the histonedeacetylase activity of HDAC3 in vivo. Nat. Struct. Mol. Biol. 2013, 20, 182-187. [CrossRef]

70. Ishizuka, T.; Lazar, M.A. The nuclear receptor corepressor deacetylase activating domain is essential for repression by thyroid hormone receptor. Mol. Endocrinol. 2005, 19, 1443-1451. [CrossRef] [PubMed]

71. Zhang, X.; Ozawa, Y.; Lee, H.; Wen, Y.D.; Tan, T.H.; Wadzinski, B.E.; Seto, E. Histone deacetylase 3 (HDAC3) activity is regulated by interaction with protein serine/threonine phosphatase 4. Genes Dev. 2005, 19, 827-839. [CrossRef] [PubMed] 
72. Karagianni, P.; Wong, J. HDAC3: Taking the SMRT-N-CoRrect road to repression. Oncogene 2007, 26, 5439-5449. [CrossRef]

73. Yoon, H.G.; Choi, Y.; Cole, P.A.; Wong, J. Reading and function of a histone code involved in targeting corepressor complexes for repression. Mol. Cell. Biol. 2005, 25, 324-335. [CrossRef] [PubMed]

74. Perissi, V.; Aggarwal, A.; Glass, C.K.; Rose, D.W.; Rosenfeld, M.G. A corepressor/coactivator exchange complex required for transcriptional activation by nuclear receptors and other regulated transcription factors. Cell 2004, 116, 511-526. [CrossRef]

75. Heinen, C.A.; Losekoot, M.; Sun, Y.; Watson, P.J.; Fairall, L.; Joustra, S.D.; Zwaveling-Soonawala, N.; Oostdijk, W.; van den Akker, E.L.; Alders, M.; et al. Mutations in TBL1X Are Associated With Central Hypothyroidism. J. Clin. Endocrinol. Metab. 2016, 101, 4564-4573. [CrossRef] [PubMed]

76. Weiss, C.; Schneider, S.; Wagner, E.F.; Zhang, X.; Seto, E.; Bohmann, D. JNK phosphorylation relieves HDAC3-dependent suppression of the transcriptional activity of c-Jun. EMBO J. 2003, 22, 3686-3695. [CrossRef] [PubMed]

77. Emmett, M.J.; Lazar, M.A. Integrative regulation of physiology by histone deacetylase 3. Nat. Rev. Mol. Cell. Biol. 2019, 20, 102-115. [CrossRef] [PubMed]

78. Montgomery, R.L.; Potthoff, M.J.; Haberland, M.; Qi, X.; Matsuzaki, S.; Humphries, K.M.; Richardson, J.A.; Bassel-Duby, R.; Olson, E.N. Maintenance of cardiac energy metabolism by histone deacetylase 3 in mice. J. Clin. Investig. 2008, 118, 3588-3597. [CrossRef] [PubMed]

79. Lewandowski, S.L.; Janardhan, H.P.; Smee, K.M.; Bachman, M.; Sun, Z.; Lazar, M.A.; Trivedi, C.M. Histone deacetylase 3 modulates Tbx5 activity to regulate early cardiogenesis. Hum. Mol. Genet. 2014, 23, 3801-3809. [CrossRef] [PubMed]

80. Poleshko, A.; Shah, P.P.; Gupta, M.; Babu, A.; Morley, M.P.; Manderfield, L.J.; Ifkovits, J.L.; Calderon, D.; Aghajanian, H.; Sierra-Pagán, J.E.; et al. Genome-Nuclear Lamina Interactions Regulate Cardiac Stem Cell Lineage Restriction. Cell 2017, 171, 573-587.e514. [CrossRef]

81. Knutson, S.K.; Chyla, B.J.; Amann, J.M.; Bhaskara, S.; Huppert, S.S.; Hiebert, S.W. Liver-specific deletion of histone deacetylase 3 disrupts metabolic transcriptional networks. EMBO J. 2008, 27, 1017-1028. [CrossRef] [PubMed]

82. Feng, D.; Liu, T.; Sun, Z.; Bugge, A.; Mullican, S.E.; Alenghat, T.; Liu, X.S.; Lazar, M.A. A circadian rhythm orchestrated by histone deacetylase 3 controls hepatic lipid metabolism. Science 2011, 331, 1315-1319. [CrossRef]

83. Sun, Z.; Miller, R.A.; Patel, R.T.; Chen, J.; Dhir, R.; Wang, H.; Zhang, D.; Graham, M.J.; Unterman, T.G.; Shulman, G.I.; et al. Hepatic Hdac3 promotes gluconeogenesis by repressing lipid synthesis and sequestration. Nat. Med. 2012, 18, 934-942. [CrossRef]

84. Mullican, S.E.; Gaddis, C.A.; Alenghat, T.; Nair, M.G.; Giacomin, P.R.; Everett, L.J.; Feng, D.; Steger, D.J.; Schug, J.; Artis, D.; et al. Histone deacetylase 3 is an epigenomic brake in macrophage alternative activation. Genes Dev. 2011, 25, 2480-2488. [CrossRef]

85. Navabi, N.; Whitt, J.; Wu, S.E.; Woo, V.; Moncivaiz, J.; Jordan, M.B.; Vallance, B.A.; Way, S.S.; Alenghat, T. Epithelial Histone Deacetylase 3 Instructs Intestinal Immunity by Coordinating Local Lymphocyte Activation. Cell Rep. 2017, 19, 1165-1175. [CrossRef] [PubMed]

86. Singh, N.; Gupta, M.; Trivedi, C.M.; Singh, M.K.; Li, L.; Epstein, J.A. Murine craniofacial development requires Hdac3-mediated repression of Msx gene expression. Dev. Biol. 2013, 377, 333-344. [CrossRef]

87. Feigenson, M.; Shull, L.C.; Taylor, E.L.; Camilleri, E.T.; Riester, S.M.; van Wijnen, A.J.; Bradley, E.W.; Westendorf, J.J. Histone Deacetylase 3 Deletion in Mesenchymal Progenitor Cells Hinders Long Bone Development. J. Bone Miner. Res. 2017, 32, $2453-2465$. [CrossRef] [PubMed]

88. Norwood, J.; Franklin, J.M.; Sharma, D.; D'Mello, S.R. Histone deacetylase 3 is necessary for proper brain development. J. Biol. Chem. 2014, 289, 34569-34582. [CrossRef] [PubMed]

89. Wang, Y.; Frank, D.B.; Morley, M.P.; Zhou, S.; Wang, X.; Lu, M.M.; Lazar, M.A.; Morrisey, E.E. HDAC3-Dependent Epigenetic Pathway Controls Lung Alveolar Epithelial Cell Remodeling and Spreading via miR-17-92 and TGF- $\beta$ Signaling Regulation. Dev. Cell 2016, 36, 303-315. [CrossRef] [PubMed]

90. Emmett, M.J.; Lim, H.W.; Jager, J.; Richter, H.J.; Adlanmerini, M.; Peed, L.C.; Briggs, E.R.; Steger, D.J.; Ma, T.; Sims, C.A.; et al. Histone deacetylase 3 prepares brown adipose tissue for acute thermogenic challenge. Nature 2017, 546, 544-548. [CrossRef]

91. Hong, S.; Zhou, W.; Fang, B.; Lu, W.; Loro, E.; Damle, M.; Ding, G.; Jager, J.; Zhang, S.; Zhang, Y.; et al. Dissociation of muscle insulin sensitivity from exercise endurance in mice by HDAC3 depletion. Nat. Med. 2017, 23, 223-234. [CrossRef]

92. Remsberg, J.R.; Ediger, B.N.; Ho, W.Y.; Damle, M.; Li, Z.; Teng, C.; Lanzillotta, C.; Stoffers, D.A.; Lazar, M.A. Deletion of histone deacetylase 3 in adult beta cells improves glucose tolerance via increased insulin secretion. Mol. Metab. 2017, 6, 30-37. [CrossRef] [PubMed]

93. Sarkar, R.; Banerjee, S.; Amin, S.A.; Adhikari, N.; Jha, T. Histone deacetylase 3 (HDAC3) inhibitors as anticancer agents: A review. Eur. J. Med. Chem. 2020, 192, 112171. [CrossRef]

94. Bates, S.E. Epigenetic Therapies for Cancer. N. Engl. J. Med. 2020, 383, 650-663. [CrossRef]

95. Wondisford, F.E. Thyroid hormone action: Insight from transgenic mouse models. J. Investig. Med. 2003, 51, 215-220. [CrossRef] [PubMed]

96. Koibuchi, N. Animal models to study thyroid hormone action in cerebellum. Cerebellum 2009, 8, 89-97. [CrossRef] [PubMed]

97. Ishizuka, T.; Lazar, M.A. The N-CoR/histone deacetylase 3 complex is required for repression by thyroid hormone receptor. Mol. Cell. Biol. 2003, 23, 5122-5131. [CrossRef] [PubMed]

98. Alenghat, T.; Yu, J.; Lazar, M.A. The N-CoR complex enables chromatin remodeler SNF2H to enhance repression by thyroid hormone receptor. EMBO J. 2006, 25, 3966-3974. [CrossRef] [PubMed] 
99. Urvalek, A.M.; Gudas, L.J. Retinoic acid and histone deacetylases regulate epigenetic changes in embryonic stem cells. J. Biol. Chem. 2014, 289, 19519-19530. [CrossRef]

100. Malinen, M.; Saramäki, A.; Ropponen, A.; Degenhardt, T.; Väisänen, S.; Carlberg, C. Distinct HDACs regulate the transcriptional response of human cyclin-dependent kinase inhibitor genes to Trichostatin A and 1alpha,25-dihydroxyvitamin D3. Nucleic Acids Res. 2008, 36, 121-132. [CrossRef]

101. Jimenez, J.J.; Chale, R.S.; Abad, A.C.; Schally, A.V. Acute promyelocytic leukemia (APL): A review of the literature. Oncotarget 2020, 11, 992-1003. [CrossRef] [PubMed]

102. de Thé, H.; Pandolfi, P.P.; Chen, Z. Acute Promyelocytic Leukemia: A Paradigm for Oncoprotein-Targeted Cure. Cancer Cell 2017, 32, 552-560. [CrossRef]

103. Atsumi, A.; Tomita, A.; Kiyoi, H.; Naoe, T. Histone deacetylase 3 (HDAC3) is recruited to target promoters by PML-RARalpha as a component of the N-CoR co-repressor complex to repress transcription in vivo. Biochem. Biophys. Res. Commun. 2006, 345, 1471-1480. [CrossRef]

104. Villa, R.; Morey, L.; Raker, V.A.; Buschbeck, M.; Gutierrez, A.; De Santis, F.; Corsaro, M.; Varas, F.; Bossi, D.; Minucci, S.; et al. The methyl-CpG binding protein MBD1 is required for PML-RARalpha function. Proc. Natl. Acad. Sci. USA 2006, 103, $1400-1405$. [CrossRef]

105. Matthews, G.M.; Mehdipour, P.; Cluse, L.A.; Falkenberg, K.J.; Wang, E.; Roth, M.; Santoro, F.; Vidacs, E.; Stanley, K.; House, C.M.; et al. Functional-genetic dissection of HDAC dependencies in mouse lymphoid and myeloid malignancies. Blood 2015, 126, 2392-2403. [CrossRef] [PubMed]

106. Lazar, M.A.; Hodin, R.A.; Darling, D.S.; Chin, W.W. A novel member of the thyroid/steroid hormone receptor family is encoded by the opposite strand of the rat c-erbA alpha transcriptional unit. Mol. Cell. Biol. 1989, 9, 1128-1136. [CrossRef] [PubMed]

107. Sap, J.; Muñoz, A.; Damm, K.; Goldberg, Y.; Ghysdael, J.; Leutz, A.; Beug, H.; Vennström, B. The c-erb-A protein is a high-affinity receptor for thyroid hormone. Nature 1986, 324, 635-640. [CrossRef]

108. Weinberger, C.; Thompson, C.C.; Ong, E.S.; Lebo, R.; Gruol, D.J.; Evans, R.M. The c-erb-A gene encodes a thyroid hormone receptor. Nature 1986, 324, 641-646. [CrossRef]

109. Kim, Y.H.; Marhon, S.A.; Zhang, Y.; Steger, D.J.; Won, K.J.; Lazar, M.A. Rev-erb $\alpha$ dynamically modulates chromatin looping to control circadian gene transcription. Science 2018, 359, 1274-1277. [CrossRef]

110. Olivieri, D.; Castelli, E.; Kawamura, Y.K.; Papasaikas, P.; Lukonin, I.; Rittirsch, M.; Hess, D.; Smallwood, S.A.; Stadler, M.B.; Peters, A.H.F.M.; et al. Cooperation between HDAC3 and DAX1 mediates lineage restriction of embryonic stem cells. EMBO J. 2021, 40 , e106818. [CrossRef]

111. Cui, S.; Kolodziej, K.E.; Obara, N.; Amaral-Psarris, A.; Demmers, J.; Shi, L.; Engel, J.D.; Grosveld, F.; Strouboulis, J.; Tanabe, O. Nuclear receptors TR2 and TR4 recruit multiple epigenetic transcriptional corepressors that associate specifically with the embryonic $\beta$-type globin promoters in differentiated adult erythroid cells. Mol. Cell. Biol. 2011, 31, 3298-3311. [CrossRef] [PubMed]

112. Sun, G.; Yu, R.T.; Evans, R.M.; Shi, Y. Orphan nuclear receptor TLX recruits histone deacetylases to repress transcription and regulate neural stem cell proliferation. Proc. Natl. Acad. Sci. USA 2007, 104, 15282-15287. [CrossRef] [PubMed]

113. Shibata, H.; Nawaz, Z.; Tsai, S.Y.; O’Malley, B.W.; Tsai, M.J. Gene silencing by chicken ovalbumin upstream promoter-transcription factor I (COUP-TFI) is mediated by transcriptional corepressors, nuclear receptor-corepressor (N-CoR) and silencing mediator for retinoic acid receptor and thyroid hormone receptor (SMRT). Mol. Endocrinol. 1997, 11, 714-724. [CrossRef] [PubMed]

114. Wong, M.M.; Guo, C.; Zhang, J. Nuclear receptor corepressor complexes in cancer: Mechanism, function and regulation. Am. J. Clin. Exp. Urol. 2014, 2, 169-187. [PubMed]

115. Patel, H.K.; Bihani, T. Selective estrogen receptor modulators (SERMs) and selective estrogen receptor degraders (SERDs) in cancer treatment. Pharmacol. Ther. 2018, 186, 1-24. [CrossRef] [PubMed]

116. Liu, X.F.; Bagchi, M.K. Recruitment of distinct chromatin-modifying complexes by tamoxifen-complexed estrogen receptor at natural target gene promoters in vivo. J. Biol. Chem. 2004, 279, 15050-15058. [CrossRef]

117. Berrevoets, C.A.; Umar, A.; Brinkmann, A.O. Antiandrogens: Selective androgen receptor modulators. Mol. Cell Endocrinol. 2002, 198, 97-103. [CrossRef]

118. Ishii, S.; Yamada, M.; Satoh, T.; Monden, T.; Hashimoto, K.; Shibusawa, N.; Onigata, K.; Morikawa, A.; Mori, M. Aberrant dynamics of histone deacetylation at the thyrotropin-releasing hormone gene in resistance to thyroid hormone. Mol. Endocrinol. 2004, 18, 1708-1720. [CrossRef]

119. Dong, X.; Lutz, W.; Schroeder, T.M.; Bachman, L.A.; Westendorf, J.J.; Kumar, R.; Griffin, M.D. Regulation of relB in dendritic cells by means of modulated association of vitamin D receptor and histone deacetylase 3 with the promoter. Proc. Natl. Acad. Sci. USA 2005, 102, 16007-16012. [CrossRef]

120. Giguère, V.; Yang, N.; Segui, P.; Evans, R.M. Identification of a new class of steroid hormone receptors. Nature 1988, 331, 91-94. [CrossRef]

121. Villena, J.A.; Hock, M.B.; Chang, W.Y.; Barcas, J.E.; Giguère, V.; Kralli, A. Orphan nuclear receptor estrogen-related receptor alpha is essential for adaptive thermogenesis. Proc. Natl. Acad. Sci. USA 2007, 104, 1418-1423. [CrossRef]

122. Schreiber, S.N.; Knutti, D.; Brogli, K.; Uhlmann, T.; Kralli, A. The transcriptional coactivator PGC-1 regulates the expression and activity of the orphan nuclear receptor estrogen-related receptor alpha (ERRalpha). J. Biol. Chem. 2003, 278, 9013-9018. [CrossRef] 
123. Lerin, C.; Rodgers, J.T.; Kalume, D.E.; Kim, S.H.; Pandey, A.; Puigserver, P. GCN5 acetyltransferase complex controls glucose metabolism through transcriptional repression of PGC-1alpha. Cell Metab. 2006, 3, 429-438. [CrossRef]

124. Rodgers, J.T.; Lerin, C.; Haas, W.; Gygi, S.P.; Spiegelman, B.M.; Puigserver, P. Nutrient control of glucose homeostasis through a complex of PGC-1alpha and SIRT1. Nature 2005, 434, 113-118. [CrossRef] [PubMed]

125. Somech, R.; Shaklai, S.; Geller, O.; Amariglio, N.; Simon, A.J.; Rechavi, G.; Gal-Yam, E.N. The nuclear-envelope protein and transcriptional repressor LAP2beta interacts with HDAC3 at the nuclear periphery, and induces histone H4 deacetylation. J. Cell Sci. 2005, 118, 4017-4025. [CrossRef] [PubMed]

126. Lewandowski, S.L.; Janardhan, H.P.; Trivedi, C.M. Histone Deacetylase 3 Coordinates Deacetylase-independent Epigenetic Silencing of Transforming Growth Factor- $\beta 1$ (TGF- $\beta 1$ ) to Orchestrate Second Heart Field Development. J. Biol. Chem. 2015, 290, 27067-27089. [CrossRef]

127. Nguyen, H.C.B.; Adlanmerini, M.; Hauck, A.K.; Lazar, M.A. Dichotomous engagement of HDAC3 activity governs inflammatory responses. Nature 2020, 584, 286-290. [CrossRef] [PubMed]

128. Chen, L.F.; Fischle, W.; Verdin, E.; Greene, W.C. Duration of nuclear NF-kappaB action regulated by reversible acetylation. Science 2001, 293, 1653-1657. [CrossRef]

129. Zhang, F.; Qi, L.; Feng, Q.; Zhang, B.; Li, X.; Liu, C.; Li, W.; Liu, Q.; Yang, D.; Yin, Y.; et al. HIPK2 phosphorylates HDAC3 for NF-kB acetylation to ameliorate colitis-associated colorectal carcinoma and sepsis. Proc. Natl. Acad. Sci. USA 2021, 118. [CrossRef]

130. Thevenet, L.; Méjean, C.; Moniot, B.; Bonneaud, N.; Galéotti, N.; Aldrian-Herrada, G.; Poulat, F.; Berta, P.; Benkirane, M.; Boizet-Bonhoure, B. Regulation of human SRY subcellular distribution by its acetylation/deacetylation. EMBO J. 2004, 23, 3336-3345. [CrossRef]

131. Takami, Y.; Nakayama, T. N-terminal region, C-terminal region, nuclear export signal, and deacetylation activity of histone deacetylase-3 are essential for the viability of the DT40 chicken B cell line. J. Biol. Chem. 2000, 275, 16191-16201. [CrossRef]

132. Yang, W.M.; Tsai, S.C.; Wen, Y.D.; Fejer, G.; Seto, E. Functional domains of histone deacetylase-3. J. Biol. Chem. 2002, 277, 9447-9454. [CrossRef]

133. Gao, Z.; He, Q.; Peng, B.; Chiao, P.J.; Ye, J. Regulation of nuclear translocation of HDAC3 by IkappaBalpha is required for tumor necrosis factor inhibition of peroxisome proliferator-activated receptor gamma function. J. Biol. Chem. 2006, 281, $4540-4547$. [CrossRef]

134. Bacon, T.; Seiler, C.; Wolny, M.; Hughes, R.; Watson, P.; Schwabe, J.; Grigg, R.; Peckham, M. Histone deacetylase 3 indirectly modulates tubulin acetylation. Biochem. J. 2015, 472, 367-377. [CrossRef] 